\title{
THE ISOELECTRIC POINT OF SILK
}

\author{
By Milton Harris ${ }^{1}$
}

\section{ABSTRACT}

Suspensions of silk in buffer solutions of different $\mathrm{pH}$ were prepared by grinding the dry silk fibroin to a fine powder and shaking it in the buffer solution.

Colloidal solutions of silk were prepared by dissolving the silk fibroin in a 50 per cent lithium bromide solution and dialyzing it to remove the salt. To the solutions were added known buffer mixtures and a small amount of purified quartz powder.

Electrophoretic measurements of the suspensions of silk and of the dissolved silk adsorbed on the quartz particles gave an isoelectric point at $\mathrm{pH} 2.5$.

\section{CONTENTS}

I. Introduction

II. Procedure

III. Discussion of results

558

IV. Acknowledgment

560

\section{INTRODUCTION}

A colloidal (or other) particle is said to be at its isoelectric point when the particle is electrically neutral with respect to its surrounding medium. This point is usually defined in terms of some property such as the pH of the medium. For an amphoteric substance the acidic and basic ionizations are equal at this point.

The most direct method of determining the isoelectric point is to define the conditions under which the particles do not move in an electric field. Such movement is called electrophoresis.

Electrical mobility measurements have been used in the determination of the isoelectric point of wool. ${ }^{2}$ It is the purpose of this paper to present similar measurements of silk.

Satisfactory suspensions of wool could only be prepared mechanically; that is, by grinding the wool to a fine powder, whereas silk may be readily prepared in suspensions and in colloidal solution. ${ }^{3}$ Abramson ${ }^{4}$ has shown that when quartz particles are suspended in dilute protein solutions, the protein is absorbed on the surface of the quartz particle, and the latter assumes the electrokinetic properties of the protein. This suggested a method for determining the isoelectric point of the dissolved silk.

\section{PROCEDURE}

The electrophoresis apparatus and methods used in this work were the same as used in the determination of the isoelectric point of wool. ${ }^{5}$

1 Research associate representing the American Association of Textile Chemists and Colorists.

2 M. Harris, The Isoelectric Point of Wool, B. S. Jour. Research vol. 8, pp. 779-786, 1932.

3 M. Harris and T. B. Johnson, Study of Silk Fibroin in the Dispersed State, Ind. \& Eng. Chem., vol. 22, p. 965,1930 .

H. A. Abramson, The Adsorption of Serum Proteins by Quartz and Paraffin Oil, J. Gen. Physiol., vol. 13 , pp. 169-177, 1929.

:See footnote 2 
'The silk was purified as follows: A sample of raw China silk was boiled successively in three $\frac{1}{2}$ per cent solutions of soap for 20 minutes each. It was then washed with distilled water, dilute ammonia, dilute hydrochloric acid, and finally repeatedly with distilled water, at $60^{\circ} \mathrm{C}$. It was then air dried for 24 hours.

One portion of the purified silk was ground in a Wiley mill. The size of the silk particles varied from $5 \mu$ to $30 \mu$. A small amount of the ground silk was shaken vigorously with distilled water, and the larger particles allowed to settle. The upper portion was carefully decanted and used for one set of measurements.

A second portion of approximately $5 \mathrm{~g}$ of the silk was dissolved in $50 \mathrm{ml}$ of a 50 per cent solution of lithium bromide at about $80^{\circ} \mathrm{C}$. The solution was diluted to $200 \mathrm{ml}$, treated with a few drops of toluene to prevent bacterial action and dialyzed in a cellophane bag against distilled water until it gave no test for $\mathrm{LiBr}$. Approximately $20 \mathrm{ml}$ of the resultant solution of silk was diluted to $200 \mathrm{ml}$ and the purified quartz particles described below were added. The silkcoated quartz thus obtained was used for the second set of measurements.

Quartz particles (size range $5 \mu$ to $20 \mu$ ) were purified as described by Abramson. ${ }^{6}$ Crude quartz powder was heated with a cleaning solution consisting of concentrated sulphuric acid saturated with sodium dichromate and diluted with water, for about 30 minutes. The particles were allowed to settle and the excess acid carefully decanted. A large amount of distilled water was added and the quartz suspension was filtered. The powder was washed with distilled water and then boiled with an excess of normal hydrochloric acid and allowed to settle. It was again filtered and washed with water for 48 hours.

In making the suspension to be studied, a very small amount of the quartz powder was added to the silk solution, which made it faintly cloudy:

Portions of each of these suspensions were mixed with equal volumes of the following buffer mixtures ${ }^{7}$ with double the usual concentrations: $\mathrm{pH} 1.4$ to 2.2 , potassium chloride-hydrochloric acid mixture; $\mathrm{pH} 2.4$ to 3.8 , acid potassium phthalate-hydrochloric acid mixture; $\mathrm{pH} 4.0$ to 6.0 , acid potassium phthalate-sodium hydroxide mixtures.

\section{DISCUSSION OF RESULTS}

The mobilities of the particles recorded in the following table are the averages calculated from 10 observations.

TABLE 1.-Electrophoretic mobility of silk (relative velocity)

\begin{tabular}{|c|c|c||c|c|c|}
\hline $\mathrm{pH}$ & $\begin{array}{c}\text { Ground } \\
\text { silk }\end{array}$ & $\begin{array}{c}\text { Dissolved } \\
\text { silk+ } \\
\text { quartz }\end{array}$ & $\mathrm{pH}$ & $\begin{array}{c}\text { Ground } \\
\text { silk }\end{array}$ & $\begin{array}{c}\text { Dissolved } \\
\text { silk+ } \\
\text { quartz }\end{array}$ \\
\hline 1.42 & +1.20 & +1.14 & 2.86 & $-\mathbf{0 . 4 8}$ & -0.36 \\
1.84 & +.73 & +.79 & 3.00 & -.57 & -.58 \\
2.13 & +.48 & +.37 & 3.33 & -.88 & -.82 \\
2.30 & +.24 & +.26 & 3.69 & -1.15 & -1.27 \\
2.54 & -.14 & +.11 & 4.21 & -1.37 & -1.40 \\
\hline
\end{tabular}

${ }^{6}$ See footnote 4 , p. 557.

. M. Clark, The Determination of Hydrogen Ions, pp. 106-107, Williams \& Wilkins Co. 
These data are shown in graphical form in Figure 1. The isoelectric point of silk obtained from the $\mathrm{pH}$-mobility curve is $\mathrm{pH} 2.5$. This value is in good agreement with the values obtained by Hawley and Johnson ${ }^{8}$ and by Harris and Johnson ${ }^{9}$ but not in agreement with those obtained by Meunier and Rey ${ }^{10}$ and Denham and Brash. ${ }^{11}$

Hawley and Johnson employed a $U$ tube electrophoresis cell and obtained values in the range from $\mathrm{pH} 1.4$ to 2.8. Since the diameter of the cell was comparatively large, diffusion and convection currents

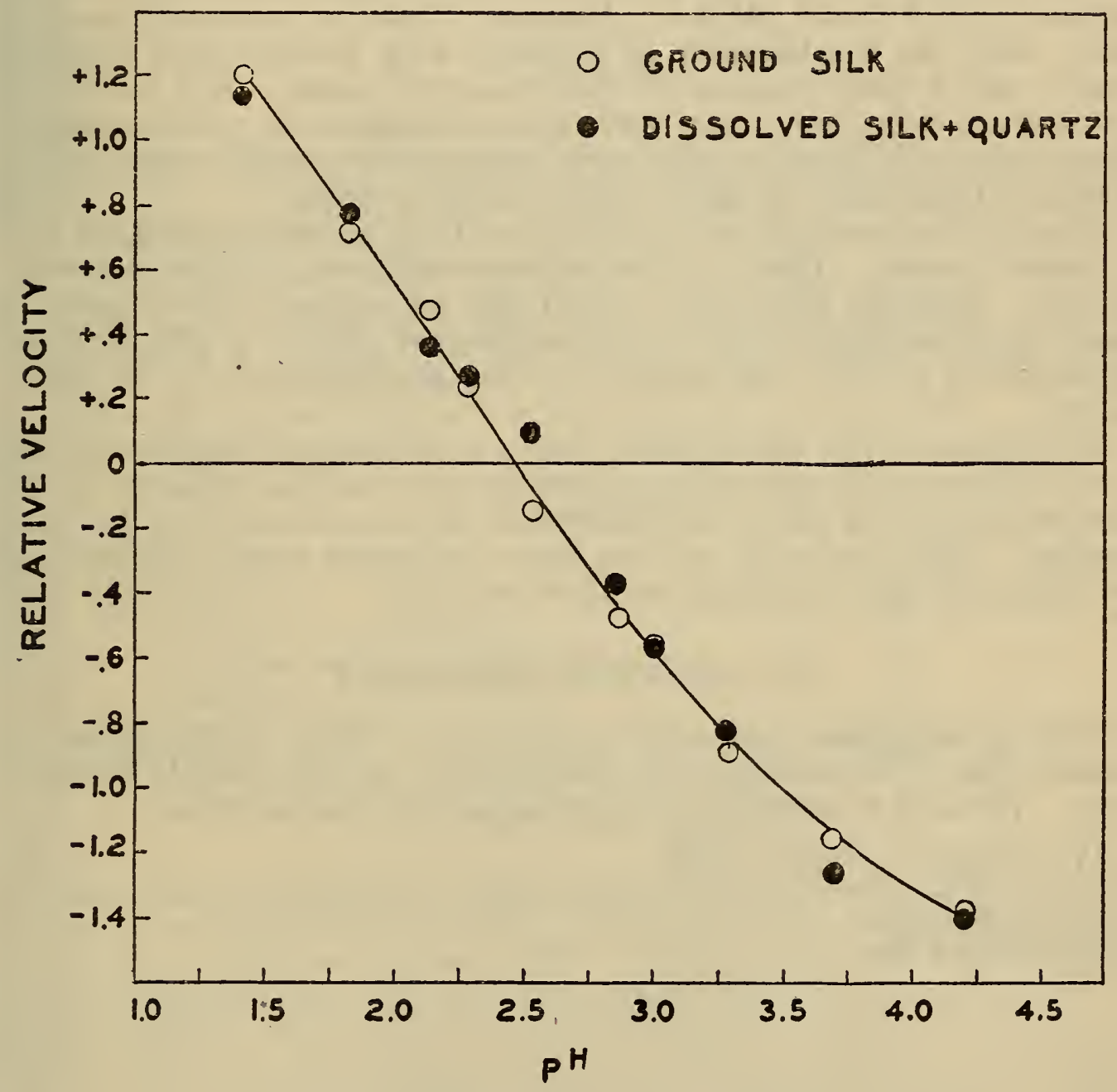

FiguRe 1.-pH-mobility: curve for silk

made"it difficult to detect small changes in protein concentration in the anode and cathode regions.

Harris and Johnson prepared solutions of silk fibroin by dissolving the degummed silk in concentrated aqueous solutions of lithium bromide and calcium thiocyanate. From solubility and viscosity measurements, values ranging from $\mathrm{pH} 2.1$ to $\mathrm{pH} 2.4$ were obtained.

\footnotetext{
${ }^{8}$ T. G. Hawley and T. B. Johnson, The Isoelectric Point of Silk Fibroin, Ind. \& Eng. Chem., vol. 22, pp. 297-299, 1930 .

9 M. Harris and T. B. Johnson, Study of the Fibroin from Silk in the Isoelectric Region, Ind. \& Eng. Chem., vol. 22, pp. 539-542, 1930 .

${ }_{10} \mathrm{~L}$. Meunier and G. Rey, Determination du point isoelectrique de la laine et de la soie, Compt. rend, vol. 184, p. 285, 1927.

${ }_{11}$ W. Denham and W. Brash, The Isoelectric Point of Silk Fibroin, J. Textile Inst., vol. 18, p. T520-525, 1927.
} 
Meunier and Rey reported an isoelectric point for silk at $\mathrm{pH} 4.2$. Their results were based on the swelling of the fiber in solutions of varying hydrogen ion concentration. The curve which they obtained is flat in the region from about $\mathrm{pH} 3$ to $\mathrm{pH} 6$ and shows no well defined point of minimum swelling.

Denham and Brash studied the combination of acidic and basic radicals with the silk fibroin when the latter was placed in solutions of acids, bases, and salts. They, too, were unable to obtain a definite isoelectric point and concluded from their experiments that it lies between $\mathrm{pH} 3.6$ and $\mathrm{pH}$ 4.0. However, there is ample evidence to show that the combination of proteins with positive and negative ions is not a true measure of the isoelectric point. The isoelectric point is a point of minimum and not zero ionization. Consequently the protein will combine with both positive and negative ions within a certain range on both sides of the isoelectric point.

The low isoelectric point of silk shows it to be one of the most acid proteins known. This is in accordance with some of the properties of silk. Meunier and Rey ${ }^{12}$ found silk to contain only 7 parts of amino nitrogen per 10,000 . The pronounced affinity of silk for basic dyestuffs is further confirmation of the predominance of its acidic nature.

The shape of the $\mathrm{pH}$-mobility curve is of interest, and shows that the acidic and basic properties are less pronounced than those of wool. ${ }^{13}$ Any changes with $\mathrm{pH}$ which occur near the isoelectric point are only gradual. This accounts for the large isoelectric range obtained by workers who have used less sensitive methods.

\section{ACKNOWLEDGMENT}

This investigation was made possible by a grant to the American Association of Textile Chemists and Colorists by the Textile Foundation. We wish to express our appreciation for the aid given.

Washington, July 8, 1932.

12 See footnote 10, p. 559.

18 See footnote 2, p. 557. 